\title{
The welfare of growing bulls in different housing systems. A review
}

\author{
Ingrid Mossberg \\ Department of Animal Nutrition and Management, \\ Swedish University of Agricultural Sciences, Kungsängen Research Centre \\ S-753 23 Uppsala, Sweden
}

(Received 28 November 1994; accepted ...December 1994)

\begin{abstract}
Housing of young bulls in slatted floor buildings can be detrimental to their health and behaviour and thus to their welfare. Small space allowances, slippery flooring and hard floor surfaces influence the animals negatively. The feeding system often involves concentrate ad libitum feeding which also might be detrimental to health. However, the surface of concrete and slatted floors can be softened by rubber coating of the slats, and the space allowance can be increased by lowering stocking density. But alternative systems seem to increase the welfare of the animals. Bedded pens often improve health and behaviour, without lessening production. If straw is scarce, using divided pens with both bedding and a concrete floor or a sloped solid floor saves bedding. Housing might not be necessary at all since growing bulls can tolerate very low temperatures without any negative influence on performance and health. Providing simple sheds is a cheap alternative that allows much behavioural freedom. However, the environmental impact of these systems is not clear.
\end{abstract}

KEY WORDS: housing, welfare, cattle, health, space allowance, flooring

\section{INTRODUCTION}

The aim of this paper is to summarize research concerning the effect of housing and rearing systems on growing bulls. Such research might influence the housing of a large number of animals since bull beef was the largest contribution to beef production in the EU in 1992 (Eurostat, 1994), with $30 \%$ of all slaughtered cattle. Most of these young bulls originate from dairy breeds since dairy cows represent $69 \%$ of the total cows in the EU (MLC, 1993). In this paper, 
production, behaviour and health are considered since these parameters, along with physiological measurements, are indicators of animal welfare and animal needs. The term "need" may be defined in several elaborate ways (Jensen and Toates, 1993), but here I simply assume that systems where animals are more healthy or systems that allow animals to behave more naturally, fulfill their needs better than other systems.

Housing for growing bulls varies both between and within countries. In southern Europe, a large number of young bulls are raised in feedlots (Boucqué et al., 1992) but in many countries the most common system is to keep the animals indoors from start to slaughter, often intensively fed. Therefore, the first part of this paper will deal with different types of housing and their effect on the animals. Secondly, the effect of tethering is discussed since keeping bulls tied is not unusual. In loose housing, which is the most common system, slatted floors are widcly used and at least in Denmark and Sweden, they predominate. The type of flooring is very important to the animal's well-being and the third part of this paper will review research on this topic. The fourth section deals with space allowance per beast, and finally, the importance of roughage for the health of the bulls is discussed.

There are several other structural and social factors that influence the animals such as slat/slot width, space allowance at the trough and group size, but they are not considered in this review.

\section{TYPE OF BUILDING}

The demand for simpler housing has increased as housing costs have gone up. In Sweden, where investment costs for cattle housing are relatively high (Figure 1), the costs for agricultural buildings rose about $200 \%$ between 1980 and 1990 (Jordbruksverket, 1994). During the same period, public concerns about the welfare of farm animals have greatly increased. Thus, there is both a demand for cheaper housing as well as a need for systems that allow the bulls to stay healthy and to approach a natural behavioural repertoire, without negative influence on production.

Insulated buildings for growing cattle have been used with the good intention of protecting the animals from low winter tcmpcratures. However, the assumed gain in production that an insulated building should provide has seldom materialized in experiments. Open buildings as well as very simple solutions such as sheds or wind breaks have been used with good results. Effects of these types of buildings are reviewed below. 


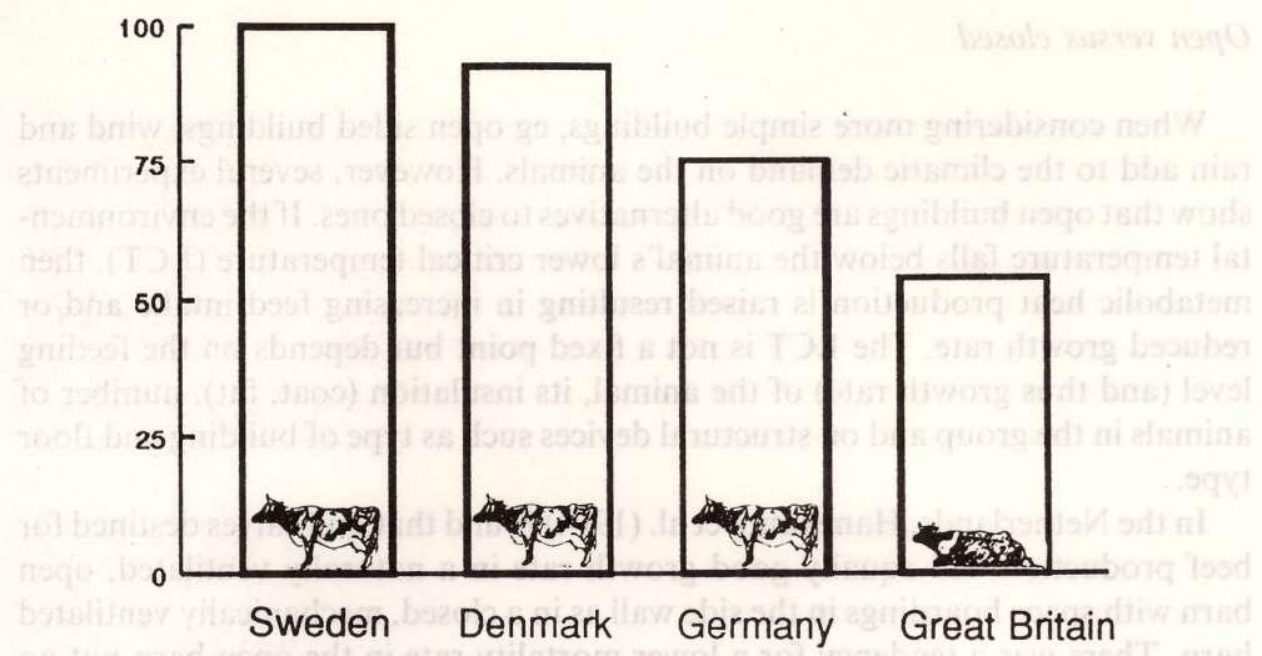

Figure 1. Relative investment costs in February 1993 for housing of milk cows (loose housing, 70 cows and replacements) in Sweden, Denmark, Germany and Great Britain (from Nilsson, 1993)

\section{Insulated versus uninsulated}

There is little, or no gain in production when insulated buildings are used instead of uninsulated ones to growing cattle. German researchers found a higher growth rate and a better feed conversion among bulls in an uninsulated building (Rintelen and Koller, 1966), while work from the Netherlands suggested a slightly better growth rate and sometimes a better feed conversion in insulated buildings (Harmsen and Smits, 1972, 1981). Research in Denmark, (Jensen and Konggaard, 1982) and in Sweden (Mossberg et al., 1991; Mossberg et al., 1993) showed no significant difference in production between the two building types.

Health seems sometimes to be better in uninsulated buildings. Jensen and Konggaard (1982) found $50 \%$ fewer respiratory diseases, along with no leg and hoof diseases, among calves and growing bulls in an uninsulated building compared with an insulated building. In one experiment, Mossberg et al. (1993) found that after slaughter, a significantly $(\mathrm{P}<0.05)$ higher frequency of pneumonic lesions was found among bulls in an insulated building compared with an uninsulated building. In another experiment, no differences in pneumonic lesions between animals in different buildings were found (Mossberg et al., 1991). Instead, there were more problems with interdigital phlegmon in the uninsulated building, probably due to dirty floors.

The behaviour of the animals is governed more by the type of interior fittings than by the actual degree of insulation. Thus, from the point of view of animals' needs, there is no readily apparent benefit of insulating cattle buildings. 
When considering more simple buildings, eg open sided buildings, wind and rain add to the climatic demand on the animals. However, several experiments show that open buildings are good alternatives to closed ones. If the environmental temperature falls below the animal's lower critical temperature (LCT), then metabolic heat production is raised resulting in increasing feed intake and/or reduced growth rate. The LCT is not a fixed point but depends on the feeding level (and thus growth rate) of the animal, its insulation (coat, fat), number of animals in the group and on structural devices such as type of building and floor type.

In the Netherlands, Hanekamp et al. (1994) found that bull calves destined for beef production had equally good growth rate in a naturally ventilated, open barn with space boardings in the side wall as in a closed, mechanically ventilated barn. There was a tendency for a lower mortality rate in the open barn but no difference was found in respiratory disorders. Ingalls and Seale (1967) compared Holstein steers and bulls kept in heated housing $\left(10\right.$ to $\left.15^{\circ} \mathrm{C}\right)$ or in open shed housing during winter in Manitoba, Canada, but found no significant difference between feed intake, growth rate and feed efficiency among animals in the two systems. Outdoor temperatures were not given.

\section{Outdoor, with or without access to simple sheds}

Where suitable land is available, a simple and cheap solution might be to outwinter the animals. In Scotland, it is not unusual to outwinter suckler cows, and it is estimated that around $45 \%$ of the cows are kept in this way (Robertson, 1994, personal communication). It is not equally common with growing cattie, but research suggests that both health and production are as good as for inwintered cattle. Also, more natural behaviour may be performed when cattle are outwintered than when they are kept indoors in pens.

Although growing bulls have been reported to elevate their feed intake in response to severe cold temperatures in Canada (Cymbaluk and Christison, 1988), outdoor rearing in winter in Great Britain did not result in significantly increased intakes or reduced growth rates or in increased health problems in Friesian steers (McCarrick and Drennan, 1972; Petchey and Mitchell, 1979). Christopherson (1985) summarised research, mainly from Canada, concerning different types of shelters for feedlot cattle. The minimum outdoor temperatures in the different experiments ranged from zero to $-40^{\circ} \mathrm{C}$ and the conclusion was that well-fed feedlot cattle should require only a minimal level of shelter. He also suggested that for young, healthy, rapidly growing cattle, simply the provision of 
more feed or a more concentrated form of feed is an alternative to winter housing. Also in Canada, Kubish et al. (1991) studied bull calves in feedlot pens with open front sheds compared with open feedlots with windbreaks. They found that animals with access to sheds gained $4 \%$ faster $(\mathrm{P}<0.05)$ than those with only windbreaks. However, significant differences between the two systems were restricted to the coldest period (mid January to mid February).

In order to study very cheap buildings for growing animals of the Swedish Red and White Breed, a small pilot study was conducted during the winter 1993-1994. A group of 11 steers was kept outside and was compared with 11 steers kept inside on slatted floors. The steers outside had access to seven ha of land and a $34 \mathrm{~m}^{2}$ simple shed with walls of porous, plastic weave on a wooden frame and a tarpaulin as a roof. The steers inside were put in two pens with an average area per animal of $2.4 \mathrm{~m}^{2}$. The winter was normal for latitude $60^{\circ}$ in the eastern part of Sweden. Mean monthly temperatures for December and January were 1.2 and

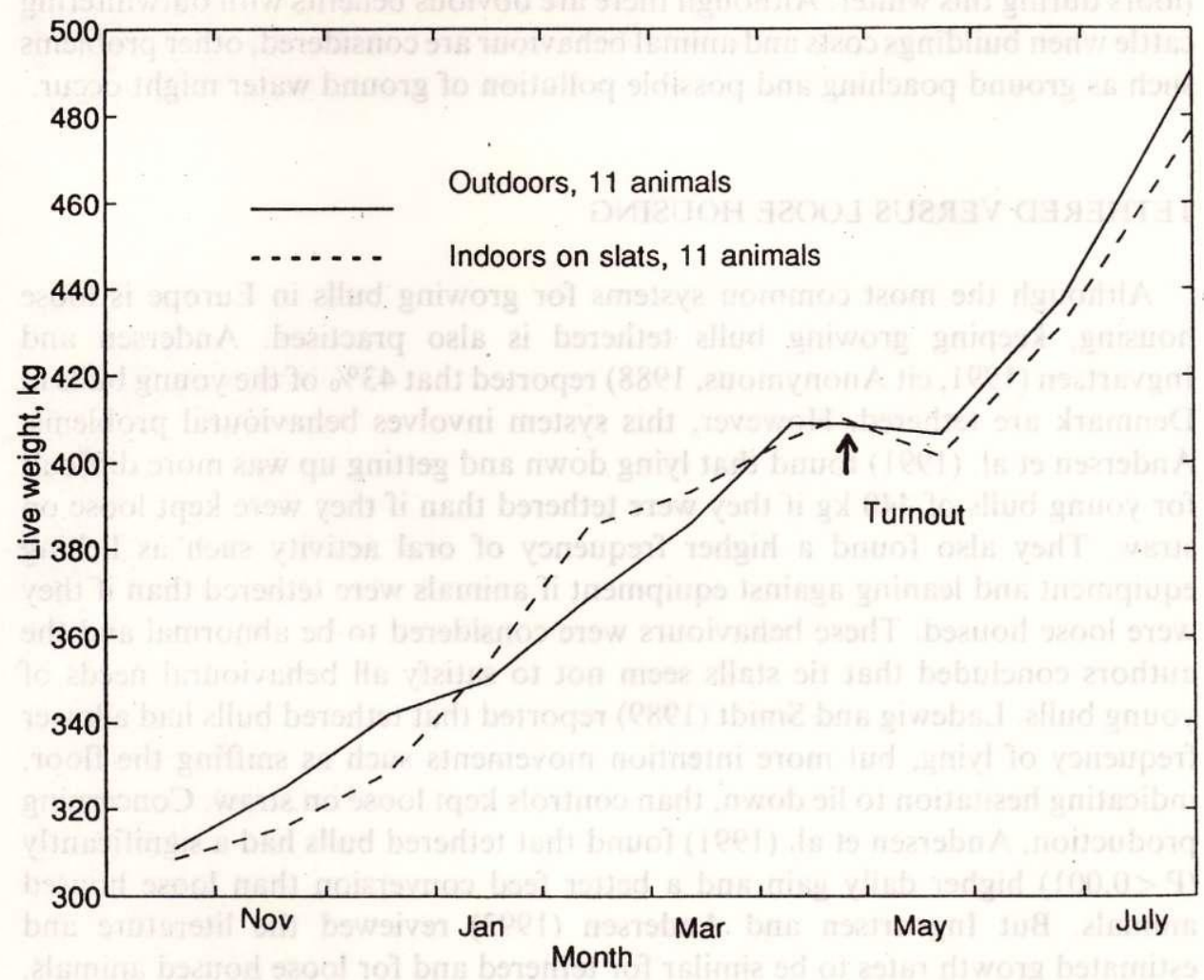

Figure 2. The change in live weight of 11 steers kept outdoors with access to a simple shelter and 11 steers indoors in slatted floor pens during the winter of 1993/94 in Sweden 
$0.9^{\circ} \mathrm{C}$ higher than the reference normal and the temperatures for February and March were 5.0 and $0.4^{\circ} \mathrm{C}$ lower than the reference normal. The lowest temperature was $-27^{\circ} \mathrm{C}$. There was no difference in average daily gain over the winter period between the two groups, but the steers kept indoors showed a decline in their growth rate starting when they were taken indoors and continuing for about two months. The outdoor steers showed no such decline (Figure 2). This suggests that the adaption to the indoor environment, adjusting to a hard, slippery flooring and restricted space in a relatively warm barn was more negative to the indoor steers than the fact that they were protected from the bad autumn weather. After they were put on pasture again, in April 1994, those who had been kept indoors again showed a more pronounced decline in weight gain than those that had been outdoors during winter. Maybe even a change that seems to be for the better from a behavioural point of view, such as being put out on pasture from being indoors in a pen, might act as a stressor on the animal. The trial suggests that the steers did not benefit from being kept indoors on slatted floors during this winter. Although there are obvious benefits with outwintering cattle when buildings costs and animal behaviour are considered, other problems such as ground poaching and possible pollution of ground water might occur.

\section{TETHERED VERSUS LOOSE HOUSING}

Although the most common systems for growing bulls in Europe is loose housing, keeping growing bulls tethered is also practised. Andersen and Ingvartsen (1991, cit Anonymous, 1988) reported that $43 \%$ of the young bulls in Denmark are tethered. However, this system involves behavioural problems. Andersen et al. (1991) found that lying down and getting up was more difficult for young bulls of $440 \mathrm{~kg}$ if they were tethered than if they were kept loose on straw. They also found a higher frequency of oral activity such as licking equipment and leaning against equipment if animals were tethered than if they were loose housed. These behaviours were considered to be abnormal and the authors concluded that tie stalls seem not to satisfy all behavioural needs of young bulls. Ladewig and Smidt (1989) reported that tethered bulls had a lower frequency of lying, but more intention movements such as sniffing the floor, indicating hesitation to lie down, than controls kept loose on straw. Concerning production, Andersen et al. (1991) found that tethered bulls had a significantly $(\mathrm{P}<0.001)$ higher daily gain and a better feed conversion than loose housed animals. But Ingvartsen and Andersen (1993) reviewed the literature and estimated growth rates to be similar for tethered and for loose housed animals. The health of tethered animals may sometimes be better than that of loose housed ones. Andersen et al. (1991) showed that tethered bulls had significantly 
$(\mathrm{P}<0.05)$ fewer incidences of foot rot as well as of liver abscesses than loose housed bulls. On the other hand, de Vries et al. (1987) reported that more severe lesions of the carpal joints were found in tethered bulls than in loose housed bulls.

\section{TYPE OF FLOORING}

The floor is a very important part of the animal's environment. Bulls have been found to lie for about $60 \%$ of the day (Kirchner, 1987). According to the needs of the animal the floor should be comfortable to lie on and non-slippery to walk on. The ideal floor should also be cheap and easy to clean. If allowed to choose for themselves, cattle prefer to stay on soft floors (Hasegawa et al., 1988). Koch (1984) found that heifers preferred deep litter to slatted floors and rubbercoated slatted floors to concrete slatted floors. The following section will compare the effects of slatted and bedded floors on animal behaviour and production and will also touch on concrete, sloped floors.

\section{Slatted versus bedded floors}

Comparisons of growth rates of animals on slatted floors and on bedded floors have often produced contradicting results. However it seems clear that slatted and concrete floors reduce the welfare of the animals since they interfere with their behaviour and increase the risk of several diseases.

Growth rate has sometimes, but not always, been equal regardless of flooring. Levy et al. (1970) found that bull calves had a significantly $(\mathrm{P}<0.01)$ higher growth rate on slatted floors than on bedding, and they also had a better $(\mathrm{P}<0.001)$ feed conversion. However, neither in Danish (Andersen et al., 1991) nor in Swedish experiments (Mossberg et al., 1991, 1993) there were any significant differences in production between animals on slatted floors or on bedding even though, in the latter experiment, space allowance was about $50 \%$ greater for the animals on bedding. Iketaki et al. (1983) found that average daily gain of steers on slatted and concrete floors was significantly lower than that of steers on bedded floors.

The behaviour of the animals is influenced by the type of flooring. Lidfors (1992) found a significantly $(\mathrm{P}<0.05)$ higher frequency of getting up and lying down among bulls in straw bedded pens compared with bulls in slatted floor pens. This is in accordance with several studies, e.g. Graf (1979), Graf (1984) and Andreae (1979) and suggests that the less slippery flooring of bedded pens help the bulls to behave in a natural way. Also, significantly higher $(\mathrm{P}<0.01)$ cortisol concentration in the blood serum was found among bulls in slatted floor pens 
than bulls in bedded pens (Unselm et al., 1982), suggesting that lying down on a slatted floor was more stressful than lying down in bedded pens. In accordance with this, Ladewig (1986) reported that secretory episodes of cortisol reached higher levels in bulls kept on slats than in bulls kept on straw.

Animal health is very much dependent on the type of flooring. The risk of severe slipping and treading on the tail is less on deep straw than in slatted pens. Tail tip lesions are almost unique to slatted floor buildings (Madsen, 1986). However not only flooring but also a high stocking density and hot temperatures may contribute to this disease (Konggaard et al., 1984). Murphy et al., (1987) found that clinical lameness was more frequent in beef cattle on concrete slats than on straw. Also bulls on slatted floors were dirtier than the others and they also had more hoof infections. On the other hand, foot problems such as foot rot and interdigital phlegmon may be the result of dirty wet bedding. There might also be a problem with excessively long claws if they are not pared. Attrell and Lidfors (1989) found that bulls on straw had $30 \%$ overgrown hooves while those on slats had none.

The warm straw bedding is very helpful to the animals during cold winters, but the extra heat in the bedding will increase the risk for heat stress during hot summer days when air temperature may be close to the upper critical temperature of the animals. Gustafsson (1988) showed that straw bedding, as opposed to a concrete floor can lower the critical temperature by $5-10^{\circ} \mathrm{C}$ depending on live weight and air velocity. In Sweden, Mossberg (1992) reported that surface temperatures in straw bedded pens ranged between 23 and $43^{\circ} \mathrm{C}$.

The hard surface of the concrete slats might be improved by coating it with rubber but the wear of claws is reduced (Irps, 1983). Another way of improving slatted floors is to reduce the number of slots, make the slats wider $(600 \mathrm{~mm})$ and sloped (1:16) (Kelly and Scott, 1989).

\section{Concrete, sloped floors}

If straw is scarce, using divided pens with both bedding and a concrete floor or a sloped solid floor saves bedding and might reduce costs. Kelly and Scott (1989) state that sloped floors were a cheaper $(6 \%)$ alternative compared with bedded courts. Slatted floor buildings had higher ( $1 \%$ to $21 \%$ depending on building design) gross capital costs than bedded courts. However, in parts of Europe (e.g. northern UK, northern Sweden and Norway) straw is scarce and buying it often becomes too expensive. Therefore, systems with very little or no straw for bedding, such as sloped floors, have been developed in several countries.

Dumelow (1993) showed that the proportion of leg problems was significantly $(\mathrm{P}<0.05)$ lower if $50 \%$ or $75 \%$ of the pen area was a sloped concrete floor than if 
the pen was fully slatted, but one problem can be the cleanliness of the animals. Animals have been found to be somewhat dirtier on sloped floors than on straw beds (Kelly, 1984). However, it is difficult to assess the effect on cleanliness as it depends on factors such as stocking density, type of feeding, the amount of straw distributed and frequency of scraping. More research is needed to assess the connection between the level of dirtiness and the welfare of animals.

\section{SPACE ALLOWANCE}

Space allowance has a great influence on the production of the animals, and some experiments also indicate that behaviour and health are influenced. Although Boucqué et al. (1992) state that the space allowance most commonly adopted for beef production in western Europe is $1 \mathrm{~m}^{2} / 100 \mathrm{~kg}$ and $0.75 \mathrm{~m}^{2} / 100 \mathrm{~kg}$ for littered and slatted floors, respectively the recommended (and sometimes decreed) space allowances vary (Figure 3).

Ingvartsen and Andersen (1993), in their thorough review, concluded that reducing the space allowance for steers or bulls from 4.7 to $1.5 \mathrm{~m}^{2}$ per animal changed feed intake, daily gain and feed conversion ration to 92,81 and $115 \%$ respectively. The analysis was based on animals kept on slatted floors and weighing 250 to $500 \mathrm{~kg}$. Andersen and Ingvartsen (1991) found that economy, calculated per pen area, was better if the animals had 2.0 to $2.5 \mathrm{~m}^{2} /$ animal than if they had less.

Concerning space allowance and behaviour, Kondo et al. (1983) and Kondo et al. (1989) found that the incidence of agonistic interactions among steers and heifers decreased when space allowance was increased. The results concerned changes from around $4 \mathrm{~m}^{2}$ to around $70 \mathrm{~m}^{2}$ /animal and were the same independent of differences in group sizes.

Allowing the animals more space reduced the incidence of tail tip necrosis of calves on slatted floors (Madsen et al., 1987). Both quantity and severity were reduced when space allowance was $1.9 \mathrm{~m}^{2} /$ animal than if it was 1.5 or 1.3 (Table 1). Madsen et al. (1987) also found a positive effect on growth rate, and the net return per calf was higher when space allowance was increased. These results suggest that if slatted floors are to be used in the future, then both the farmer's and the animals' needs are better met when the space allowance is more liberal.

\section{TYPE OF FEEDING}

When considering well-being of growing bulls, not only housing system is important but also feed type might influence health. Feeding growing bulls or 


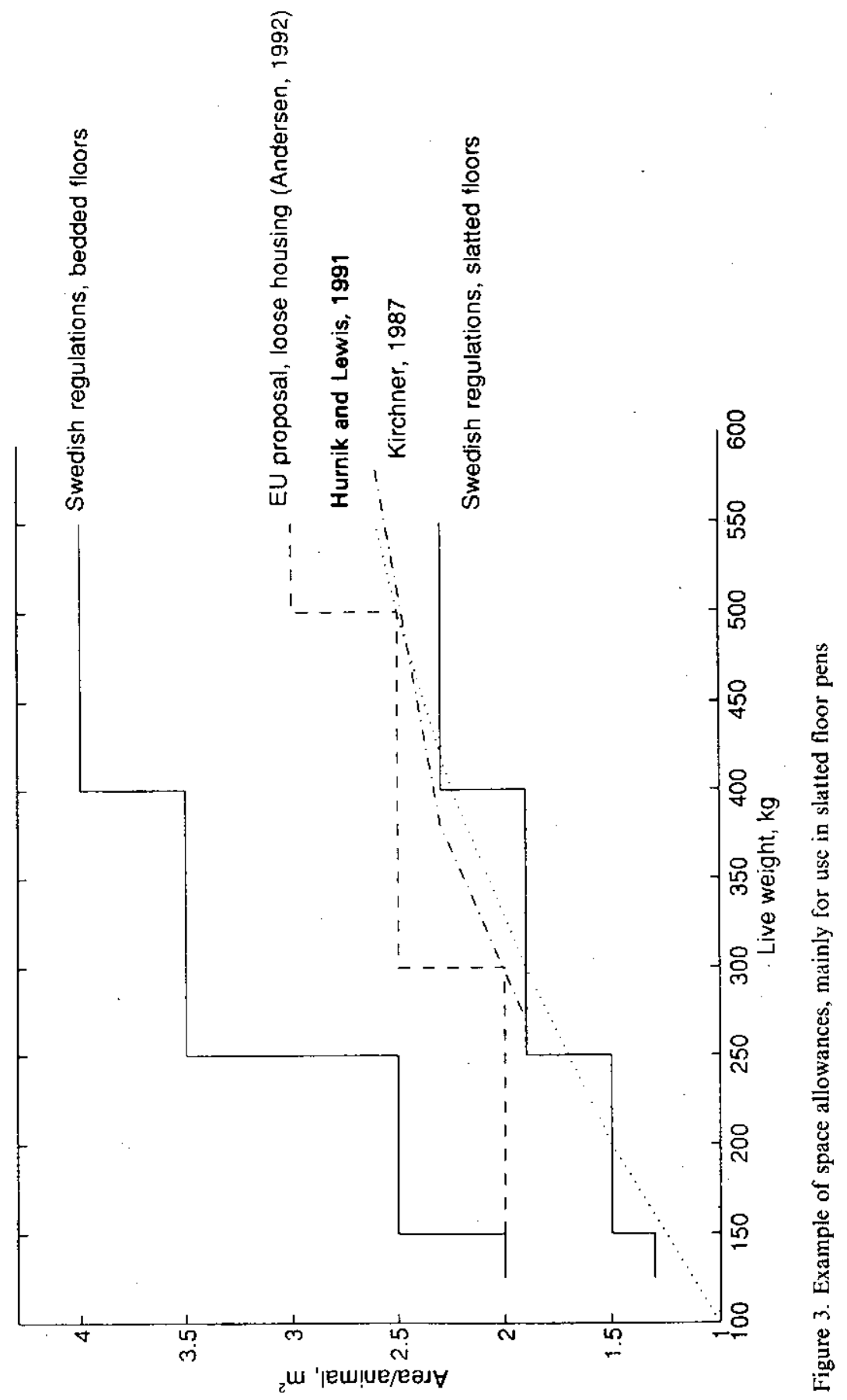


TABLE 1

Productivity, tail amputations and economic results in calf fattening from $250 \mathrm{~kg}$ in different stocking densities (from Madsen et al., 1987)

\begin{tabular}{lccc}
\hline & \multicolumn{3}{c}{ Stocking density (m² per calf) } \\
\cline { 2 - 4 } & $1.9 \mathrm{~m}^{2}$ & $1.5 \mathrm{~m}^{2}$ & $1.3 \mathrm{~m}^{2}$ \\
\hline Daily gain, $\mathrm{g}$ & 1161 & 1116 & 1010 \\
Total gain, $\mathrm{kg}$ & 174 & 167 & 152 \\
Tail amputations & 0.08 & 0.10 & 0.13 \\
Net return per calf (relative) & 181 & 173 & 100 \\
Yearly net return per pen (relative) & 128 & 148 & 100 \\
\hline
\end{tabular}

TABLE 2

Influence of feeding system and housing system on growing bulls. Results of examination made at slaughter and of animal health treatments (\%). (From Mossberg et al., 1991 and Mossberg et al., 1993)

\begin{tabular}{|c|c|c|c|c|}
\hline & \multicolumn{2}{|c|}{$\begin{array}{l}90 \% \text { concentrate } \\
\text { in diet }\end{array}$} & \multicolumn{2}{|c|}{$\begin{array}{c}50 \% \text { concentrate } \\
\text { in diet }\end{array}$} \\
\hline & $\begin{array}{c}\text { slatted } \\
\text { floor } \\
n=95\end{array}$ & $\begin{array}{c}\text { straw } \\
\text { bedding } \\
n=61\end{array}$ & $\begin{array}{c}\text { slatted } \\
\text { floor } \\
n=97\end{array}$ & $\begin{array}{c}\text { straw } \\
\text { bedding } \\
n=65\end{array}$ \\
\hline Liver abscesses & $46^{\mathrm{a}}$ & $44^{a}$ & $4^{b}$ & $0^{\mathrm{b}}$ \\
\hline Pneumonic lesions found after slaughter & $43^{a}$ & $31^{\cdot 1}$ & $33^{a}$ & $17^{\mathrm{b}}$ \\
\hline Treated for interdigital phlegmon & $3^{a}$ & $33^{b}$ & $2^{i:}$ & $3^{a}$ \\
\hline
\end{tabular}

Figures on the same line with different letter superscripts are significantly different from each other by at least $(\mathrm{P}<0.05)$.

steers concentrate ad libitum, which is a very common system when the grain price is low, involves a higher risk of disease compared with systems where a larger proportion of roughage is given (Table 2). The bulls receiving $90 \%$ concentrate and $10 \%$ hay and straw in the diet were slaughtered at $420 \mathrm{~kg}$ live weight and those receiving $50 \%$ concentrate and $50 \%$ grass silage were slaughtered at $470 \mathrm{~kg}$ live weight.

For animals kept on straw bedding, the $50 \%$ concentrate diet resulted in significantly fewer liver abscesses, pneumonic lesions after slaughter, and treatments for interdigital phlegmon compared with the $90 \%$ concentrate diet. For animals kept on slats, the difference between diets is not so clear. Thus, there seems to be an interaction between diet and flooring. 
Consistent with the results shown in Table 2, Andersen et al. (1991) found a significantly higher incidence of foot rot $(12 \%$ vs $5 \%)$ and of liver abscesses $(11 \%$ vs $2 \%$ ) when the animals were fed concentrate ad libitum than when they were fed a high content of whole crop barley silage in the diet. Also, Mwansa et al. (1992) found that feedlot calves with a start weight of $230 \mathrm{~kg} \mathrm{LW}$ had a significantly higher incidence of respiratory disease $(87.5 \%)$ when they were fed a high concentrate diet with $85 \%$ grain than when fed a low concentrate diet with $48 \%$ grain $(7.1 \%)$.

\section{CONLUSIONS}

In order to improve housing systems for growing bulls, information from different disciplines must be considered. Behaviour as well as health and production of the animals give us much more information if they are studied together rather than separately. Thus, future research in this field should be done cooperatively with ethologists, veterinarians, agricultural engineers and animal scientists working together. The emphasis must be on simple low cost buildings but reduction in housing costs must not add to the labour requirement or reduce animal welfare or productivity.

Slatted and concrete floors are not recommended because health and behaviour are impaired and thus welfare is reduced. Where straw is not available, different kinds of sloped floors can be used with little or no bedding. There is evidence to suggest that greater consideration should be given to systems without housing or with very simple shelters under North European conditions. The problems that might arise in these systems are: feed waste, poaching, and water pollution.

As was mentioned in the introduction, defining needs is a relative and subjective task involving human value judgement. However, one could argue that bulls in loose housing on soft, non slippery floors get what they need. Also, if they have space allowances of 3-4 $\mathrm{m}^{2} / \mathrm{animal}$ and are fed roughage ad libitum, they get what they need. But if they are given insulated buildings - they get more than they need, and that is not what they need.

\section{REFERENCES}

Andersen H.R., 1992. Effect of housing system and stocking density on growth, feed efficiency and meat quality of young bulls (Danish). Proceedings from the Annual Meeting of the National Institute of Animal Science, May 20, 1992. National Institute of Animal Science, Foulum Research Centre, Denmark, pp. 19 
Andersen H.R., Ingvartsen K.L.. 1991. Performance of fattening bulls dependent on housing system and stocking density (With English summary and subtitles). Report, National Institute of Animal Science, Denmark No 686, pp. 31

Andersen H.R., Krohn C.C.., Foldager J., Munksgaard L., Klastrup S., 1991. Influence of housing and feeding on behaviour, feed intake, growth and carcass and meat quality (With English summary and subtitles). Report from the National Institute of Animal Science, Denmark, No 700. pp. 39

Andreac U.. 1979. Zur Aktivitätsfrequenz von Mastbulten bei Spaltenbodenhaltung. In: Landbauforschung Völkenrode. Sonderheft 48, pp. 223

Attrell B., Lidfors L., 1989. Movement pattern and alterations in the joints of young bulls (Swedish). Fact sheet, Vetcrinary medicin. Swedish Unjversity of Agricultural Sciences, No 12, pp. 4

Boucqué CH. V., Geay Y., Fiems L.O., 1992. Bull beef production in western Europe. In: R. Jarrige, C. Béranger (Editors). Beef cattle production. Elsevier. Amsterdam, pp. 307-321

Christopherson R.J., 1985. Management and housing of animals in cold environments. In: M.K. Yousef(Editor), Stress physiology in livestock, Volume II, Ungulates. CRC Press, Boca Raton, pp. 175-194

Cymbaluk N.F., Christison G.I., 1988. Performance of growing bulls and horses in a severe winter. In: Livestock Environment III, Third International Symposium. ASAE. Toronto, Ontario, Canada, pp. 322-329

Dumelow J., 1993. Unbedded self cleaning sloped floors as alternatives to fully slatted floors for beef cattle housing. In: Livestock Environment IV, Fourth International Symposium. 6-9 July, 1993. ASAE. University of Warwick. Coventry, England, pp. 209-216

EUROSTAT. 1994, Animal Production, quarterly statistics, 1, 1994, Series 5B, Luxembourg, Brussels

Graf B., 1979. Spaltenbodenhaltung bei Mastochsen. In: Landbauforschung Völkenrode, Sonderheft 48. pp. $73-88$

Graf B., 1984. Der Einfluss unterschiedlicher Laufstallsysteme auf Verhaltensmerkmale von Mastochsen. Eidgenössischen Technischen Hochschule, Zürich. Switzerland, (Thesis), pp. 282

Gustafsson G., 1988. Air- and heat balances in animal houses. Doctor's thesis, Swedish University of Agricultural Sciences. Department of Farm Buildings, Lund. Report 59, pp. 385

Hanckamp W.J.A., Smits A.C., Wierenga H.K., 1994. Open versus closed barn and individual versus group-housing for bull calves destined for beef production. Livest. Prod. Sci. 37, 261-270

Harmsen H.E., Smits A.C., 1972. The influence of housing system on the growth of fattening bulls (Dutch). Proefstation voor de rundveehouderij. Report 8. Lelystad, Netherlands, pp. 18

Harmsen H.E., Smits A.C., 1981. Fattening bulls in insulated and uninsulated buildings (Dutch). Proefstation voor de rundveehouderij, Report 82. Lelystad, Netherlands, pp.15

Hasegawa S., Azuma Y., Gondo A., Koyama K., Watanabe S., 1988. Studies on the floor structures of free stall barn-preferences of steers for free stall materials. Bulletin, National Institute of Animal Industry, Japan. 48, 43-51

Hurnik J.F.. Lewis N.J., 1991. Use of body surface area to set minimum space allowances for confined pigs and cattle. Can. J. Anim. Sci., 71, 577-580

Iketaki T.. Ohtani M., Ota S., 1983. Effect of barn floor types on behaviour of fattening steers. In: Proceedings, Fifth World Conference on Animal Production, August 14.19, 1983, vol. 2 , Tokyo, Japan, pp. 811-812

Irps H., 1983. Resuits of rescarch projects into flooring preferences of cattle. In: S.H. Baxter, M.R. Baxter, J.A.C. MacCormack (Editors). Farm Animal Housing and Welfare, Martinus Nijhoff Publishers, The Hague, pp. 200-215

Ingalls J.R., Seale M.E., 1967. Dairy bulls and steers in open vs. heated housing. J. Anim. Sci. 26, 1467 (Abstr.) 
Ingvartsen K.L., Andersen H.R., 1993. Space allowance and type of housing for growing cattle. Acta Agric. Scand., Sect. A, Anim. Sci., 43, 65-80

Jensen V., Konggaard S.P., 1982. Production responses of young calves, fattening bulls, and replacement stock to different types of housing. In: J.P. Signoret (Editor). Current Topics in Veterinary Medicine and Animal Science, 19. Martinus Nijhoff Publishers, London, pp. 209-214

Jensen P., Toates F.M., 1993. Who needs "behavioural needs"? Motivational aspects of the needs of animals. Appi. Anim. Behaviour Sci. 37, 161-181

Jordbruksverket, 1994. The costs for agricultural buildings 1981-1990 (in Swedish), Report 1994:3, pp. 32

Kelly M., 1984. Sloped floor building for beef cattle at Moffal, Dumfriesshire. Farm Building Progr. 78. $15-20$

Kelly M., Scott G.B., 1989. New techniques in cattle housing. In: Phillips, C.J.C. (Editor). New Techniques in Cattle Production. Proceedings of the Second International Symposium on New Techniques in Agriculture, University of Wales, Bangor, UK, September 1988. Butterworth and Co. (Publishers) Ltd, London, Chapter 10, pp. 130-142

Kirchner M., 1987. Verhaltenskenndaten von Mastbullen in Vollspaltbodenbuchten und Folgerungen für die Buchtengestaltung. Institut für Landtechnik der Technishen Universität München in Weihenstephan (Doctor's Thesis)

Koch L., 1984. Wahlversuche bei Jungrindern in Bezug auf Klimafaktoren und Flächenqualitäten. Aktuclle Arbeithen zur artgemkässen Ticrhaltung. KTBL-Schrift, 307, pp. 206-220

Kondo S., Ono K., Nishino S., 1983. Differences in spatial and social behaviour between calves in groups of two different sizes. J. Coll. Dairying 10, 63-71

Kondo S., Sekine J., Okubo M., Asahida Y., 1989. The effect of group size and space allowance on the agonistic and spacing behaviour of cattle. Appl. Anim. Behav. 24, 127-135

Konggaard S.P., Larsson J.G., Madsen E.B., Niclsen K., 1984. Tail-tip lesions in young bulls (Danish). Report from the National Institute of Animal Science, No. 558. Copenhagen, Denmark. pp. 4

Kubisch H.-M., Makarechian M., Arthur P.F., 1991. A note on the influence of climatic variables and age on the response of beef calves to different housing types. Anim. Prod. 52, 400-403

Ladewig J., 1986. Physiological results of welfare research in fattening bulls. In: M.C. Schlichting, D.J. Smidt (Editors). Welfarc Aspects of Housing Systems for Veal Calves and Fattening Bulls. Procedings of an EC Scminar, Mariensce, German Fedcral Rcpublic, 16-17 September 1986, pp.123-129

Ladewig J., Smidt D., 1989. Behaviour, episodic secretion of cortisol, and adrenocortical reactivity in bulls subjected to tethering. Hormone Behav. 23, 344-360

Levy D., Holzer Z.. Volcani R.. 1970. Concrete slatted floors vs. bedding for fattening Israeli-Friesian bull calves. J. Anim. Sci. 31, 816-820

Lidfors L., 1992. Behaviour of bull calves in two different housing systems: Deep litter in an uninsulated building versus slatted floor in an insulated building. Swedish University of Agricultural Sciences. Department of Animal Hygiene, Report 30, pp. 108

Madsen E.B., 1986. Tail tip inflammation in young lattening bulls on slatted floors. In: M.C. Schlichting, D. J. Smidt (Editors). Welfare Aspects of Housing Systems for Veal Calves and Fattening Bulls. Proceedings of an EC Seminar, Mariensec, German Federal Republic, 16-17 September 1986, pp. 131-138

Madsen E. B., Thysen I., Ingvartsen K.L., Østergaard V., 1987. Health and production of young bults on slatted floors at different stocking densities (in Danish). In: V. Østergaard, J. Hindhede (Editors). Research in Cattle Production Systems. Report from the National Institute of Animal Science,No. 628, Copenhagen, Denmark, pp. 209-218 
McCarrick R.B., Drennan M.J., 1972. Effect of winter environment on growth of young beef cattle. Anim. Prod. 14, 97-105

MLC, 1993. Beef Yearbook, Meat and Livestock Commission, PO Box 44, Winterhill House, Snowdon Drive, Milton Keynes, England

Mossberg I., 1992. Environmental influences on growing bulls in two housing systems. Swedish University of Agricultural Sciences. Report 217, (Doctor's thesis)

Mossberg I., Lindell L., Johnsson S.. Törnquist M., Engstrand U., 1991. Two housing systems for intensively reared bulls slaughtered in two weight ranges. Acta Agric. Scand., Scct. A, Anim. Sci. $42,167-176$

Mossberg I., Lindell L., Johnsson S., Törnquist M., 1993. Insulated and uninsulated housing systems for growing bulls fed grass silage ad libitum. Acta Agric. Scand., Sect. A, Anim. Sci. 43. 107-115

Murphy P.A., Hannan J., Monaghan M., 1987. A survey of lameness in beef cattle housed on slats and on straw. In: H.K. Wierenga, D.J. Petersee (Editors). Current topics in veterinary medicine and animal science, 40. Martinus Nijhoff, Dordrecht, Netherlands, pp. 67.72

Mwansa P.B., Makarechian M., Berg R.T., 1992. The effect of level of concentrate in feedlot diets on the health status of beef calves. Can. Vet. J. 33, 665-668

Nilsson L., 1993. Farm buildings in Sweden and the EU (in Swedish). Fact-sheet, Agricultural Engineering, Swedish University of Agricultural Sciences, No 7, pp. 4

Petchey A.M., Mitchell C.D., 1979. The intake and performance of cattle wintered in either a roofless slatted structurc or a roofed slatted building. North of Scotland College of Agriculture, Aberdeen. Cit. by: Higgins, K.P. and Dodd, V.A., 1989. A model of the bioclimatic value of shelter to beef cattle. J. Agric. Engng Res. 42, 149-164

Rintelen von, P., Koller G., 1966. Einfluss verschiedener Stallformen auf Gewichtszunahme und Futterverbrauch in der Jungbullenmast. Baycr. Landw. Jahr. 43, 899-910

Unselm J., Andreac U., Smidt D., 1982. Biochemische Parameter im Rahmen tierschutz- und nutzungsbezogener Untersuchungen beim Rind. Fortschr. Vet.Med. 35, 220-225

\section{STRESZCZENIE}

\section{Samopoczucie rosnących buhajków utrzymywanych w różnych systemach. Praca przeglądowa}

Utrzymanie młodych buhajków w budynkach z rusztową podłogą może wpływać ujemnie na ich zdrowie i zachowanie, a stąd na ich samopoczucie. System żywienia często oparty jest na skarmianiu do woli pasz treściwych, co również może być szkodliwe dla zdrowia. Powierzchnia podłogi - betonowa lab rusztowa - może być "zmiękczona" przez pokrycie listew gumą, a dostępna dla zwierząt powierzchnia może być zwiększona przez zmniejszenie obsady. Takie alternatywne systemy mogą zwiększyć dobre samopoczucie zwierząt. Wyścielone kojce często poprawiają stan zdrowia i zachowanie się zwierząt, bez obniżenia produkcji. Przy braku słomy można zaoszczędzić materiały wyścielające przez podzielenie kojców na wyścieloną i betonową część lub pochyloną litą podłogę. Utrzymanie w pomieszczeniach nie zawsze jest konieczne, ponieważ rosnące buhaje mogą tolerować niską temperaturę bez ujemnego wplywu na wyniki produkcyjne i zdrowie. Proste szopy są tanią alternatywą i dają większą swobodę w zachowaniu się zwierząt. 